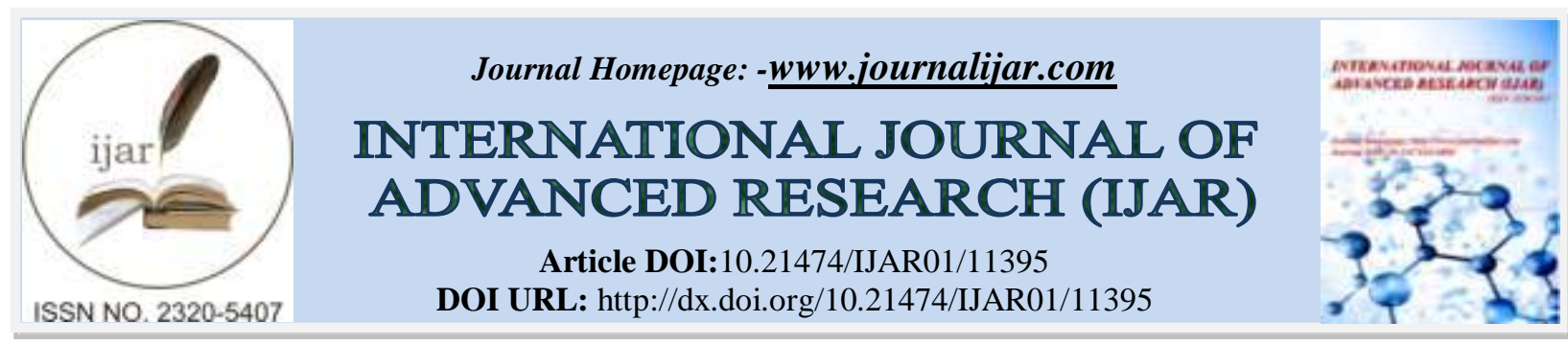

RESEARCH ARTICLE

\title{
INVESTMENT POTENTIAL OF SURKHANDARYA AREA - AN ELEMENT OF FINANCIAL POTENTIAL
}

Buranova Lola

Lecturer at Termez State University, Department of Economics and Management.

\section{Manuscript Info}

(........................

Manuscript History

Received: 25 May 2020

Final Accepted: 28 June 2020

Published: July 2020

Key words:-

Investments, Investment Potential,

Investment Attractiveness, Investment

Activity, Investment Resources

\section{Abstract}

The investment potential of the Surkhandarya region is available in the article. Different points of view of scientific economists on the nature and content of investment cooperation are examined. Subkhandarya region is an analysis of investment attractiveness. Recommendations on increasing investment cooperation are proposed.

\section{Introduction:-}

In modern conditions, the solution of the overwhelming majority of the problems of life support of the population focuses on the regional level. Of particular importance are the issues of financial potential and the provision of regions with relevant resources.

\section{The financial potential of the region consists of the following main elements:}

1. Budgetary potential of the region

2. Investment potential of the region

3. Funds of the financial and credit system

4. Financial potential of enterprises and organizations of various forms of ownership

5. Financial resources of the population of the region and financial resources attracted from outside

The potential of each element determines the degree of provision of the region with financial resources for independent and responsible solution of important socio-economic problems that are within the competence of the corresponding level of government. The investment potential of the region as an element of financial potential is considered an assessment of the investment attractiveness of the region, characterized by the volume of the tax base, profitability of enterprises and incomes of the population.

\section{Material and Method:-}

A.Margolina gives a very interesting definition of "Investment Potential": "it means in a certain way an ordered set of investment resources that make it possible to achieve a synergy effect in their use and to obtain the effect of each factor individually interacting with the object under consideration".

Trukhin S.A. believes that investment potential is determined on the basis of labor, consumer, production, financial, institutional, innovative, infrastructure and natural resource potentials [2, 201str].According to Nguyen Thi Thu Thu Thong, the concept of investment potential is determined by "Investment attractiveness" and means the presence of investment conditions that affect the investor's preferences in choosing a particular investment object [3, 91 
pp].Other researchers S.V. Zenchenko, M.A. Schechetkin identify a number of factors that influence investor preferences, which include resource and raw material supply, production activities, consumer ability, infrastructure arrangement, the intellectual level of the population, and the institutional development level of the leading institutions of the region.Such scientists as L.S. made a significant contribution to the study of theoretical and methodological foundations for determining the investment potential of a region. Valinurova, O.B.Kazakova, L.V. Davydova, S.A. Markin, I.R. Gafurov, B. B. Valiev, A. V. Vakhabov, S. S. Gulyamov and others.According to BB Valiev, investment potential is a multifaceted category, which includes a wide range of directions and indicators of an economic, social and political nature. Therefore, to assess the investment potential of a certain territory, it is necessary to take into account the objectives of the study and the characteristics of a particular region. [4, 111st]. According to Ch. Emirullah and M. Azam, to assess the investment climate it is important to take into account factors such as macroeconomic and political stability, the development of local capital markets, the managerial environment, the legislative framework, the effectiveness of government bodies, the degree of corruption and market conditions. $[6,67 \mathrm{st}]$

The Agency for Strategic Initiatives of the Russian Federation has developed the most advanced methods for assessing the investment attractiveness and investment potential of the region, which includes key factors for creating a favorable investment climate. The main part of the indicators for the rating is formed according to the results of surveys of regional entrepreneurs. All this allows us to identify roadmaps and activities of regional authorities that contribute to achieving the best results in developing the investment climate.

In the Republic of Uzbekistan, to determine the state of the investment climate in the regions, the survey is conducted jointly with the Ministry of Investments and Foreign Trade and the international company The Boston Consulting Group, in which all questions are grouped in the Regulatory Environment, Efficiency of Enterprise Registration Procedures, and Support business by government agencies ", "Administrative pressure - corruption "," Infrastructure, technologies and resources ", Human resources "and" Accessibility of SEZ / MPZ for business ".The economy of the Surkhandarya region is rich in natural and labor resources, has a certain size of the consumer market, is export-oriented, and scientific and educational reforms are being actively carried out in it. In this regard, it is advisable to use such integrated indicators as investment activity, production, natural resources, consumer, labor, infrastructure, institutional, scientific, educational, export and innovative potentials.Investment activity is determined by such indicators as the growth rate of investment in fixed assets, the share of investments in GRP, the share of foreign investment in GRP, as well as the share of the region in the development of investments in the Republic.The growth rate of investments in fixed assets is determined by the ratio of the volume of investments for the current year to the volume of investments for the previous year.
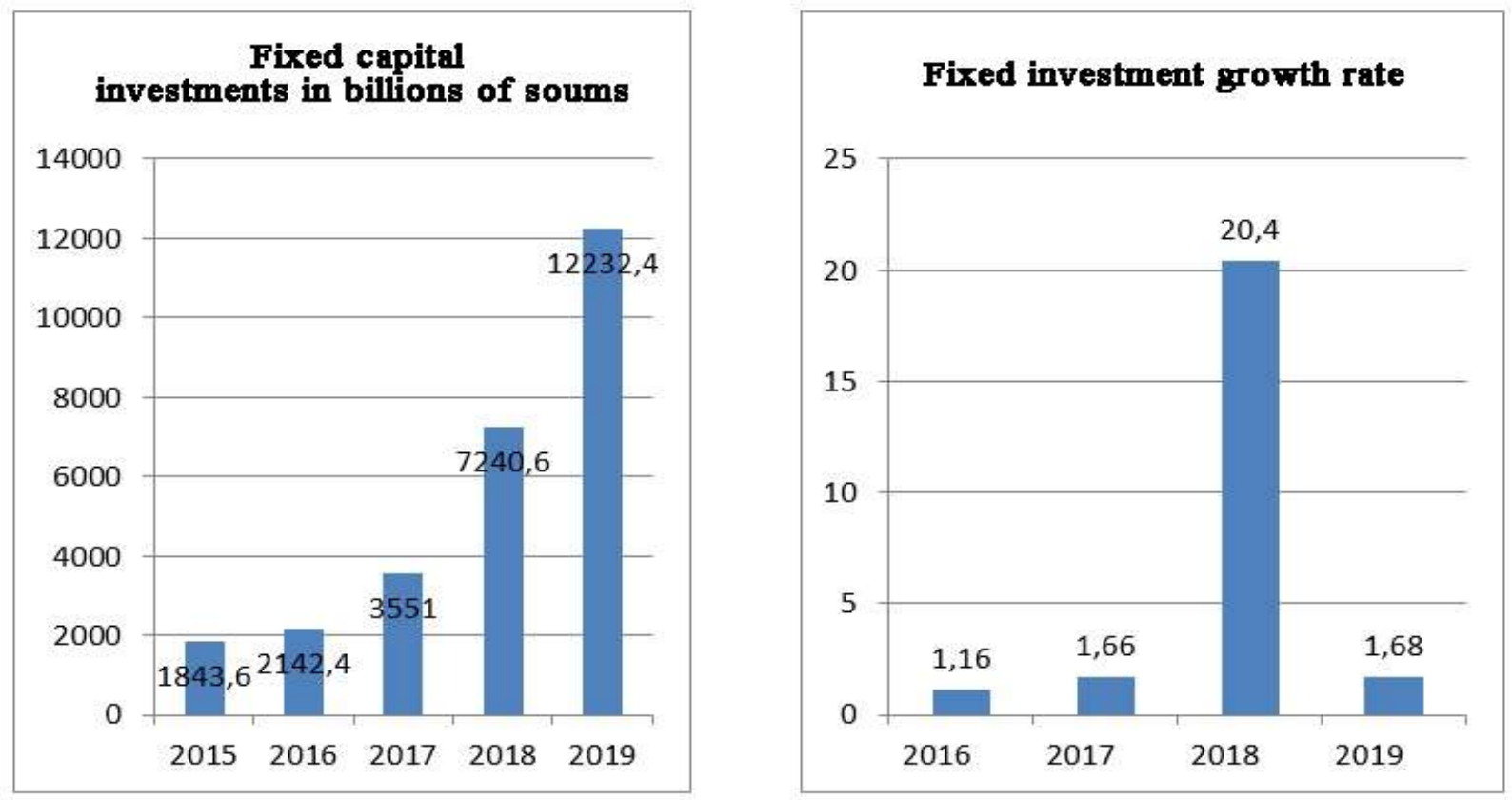

Indicators of investment activity in Surkhandarya region for 2015-2019 in billion soums: 
The diagrams show how fixed investment is increasing. In 2019, investments in the Surkhandarya region were attracted for a total amount of 12,232.4 billion sums, which increased by $148 \%$ compared to 2018 . The growth rate of investment in fixed assets of the Surkhandarya region for 2019 compared to the previous 2018 increased by 1.68 . In 2019 , there is a tendency to decrease the growth rate of investment activity in the Surkhandarya region by 18.7 units. In 2018, the growth rate of investment activity in relation to 2017 was 20.4, in relation to 2016 it was higher by 19.24 .

The share of investments in GRP of the Surkhandarya region is determined by the ratio of the volume of investments for a certain year to the volume of gross regional product by the same year.
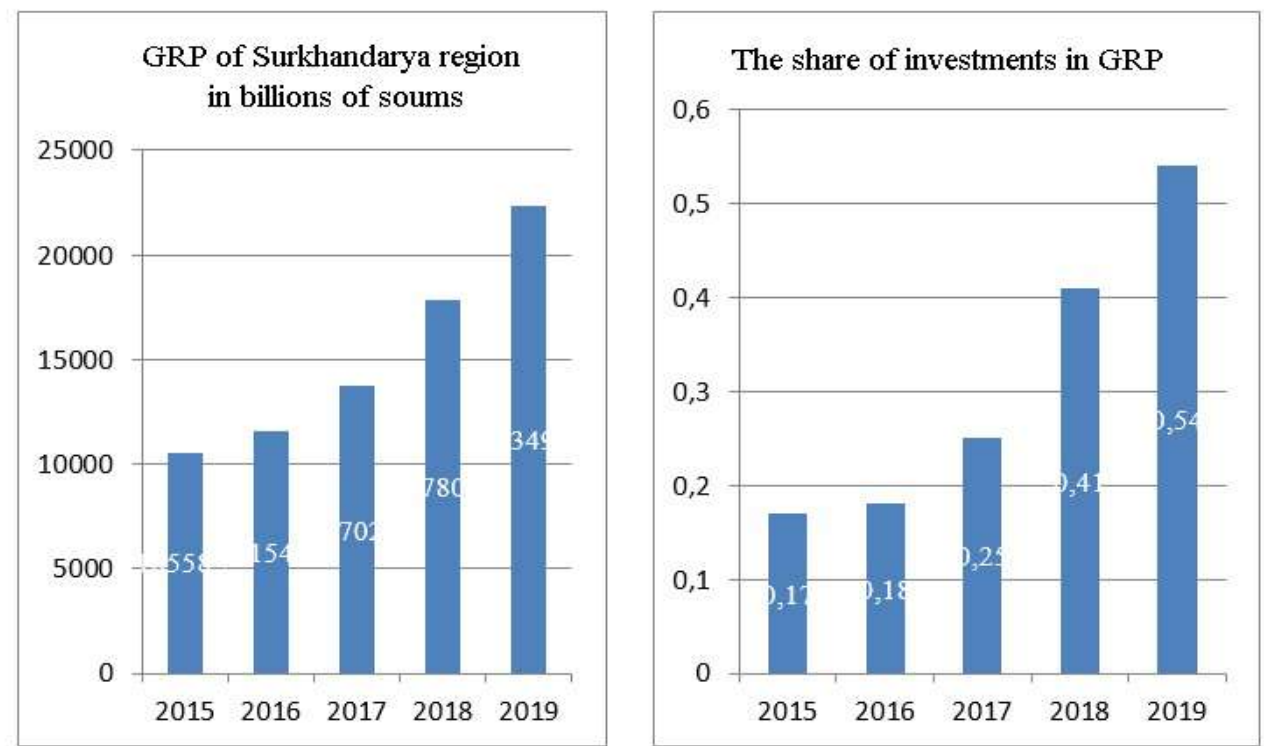

The share of investments in the GRP of the Surkhandarya region for 2015-2019 in billion soums

On the GRP diagrams of the Surkhandarya region in 2019 amounted to 22349.3 billion soums, which in relation to 2018 increased by $106.3 \%$. We determine the total share of investments in GRP of the Surkhandarya region and get positive dynamics for $2015-2019$, the average growth rate of which is 0.31 units.

Based on these indicators, it is possible to determine the share of foreign investment in the GRP of the Surkhandarya region by determining the ratio of the volume of foreign investment for a certain year to the volume of gross regional product by the same year, as well as the region's share of investment development in the republic.

\section{The share of foreign investment in GRP}

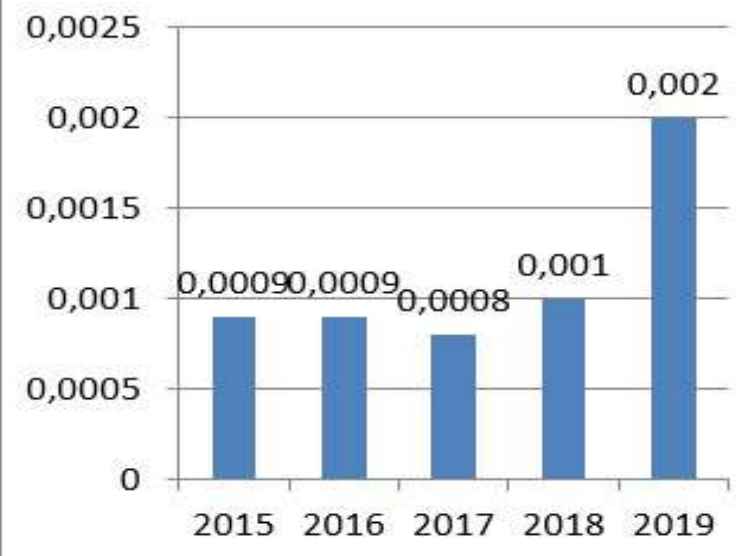

The share of the region in the development of investments in the Republic

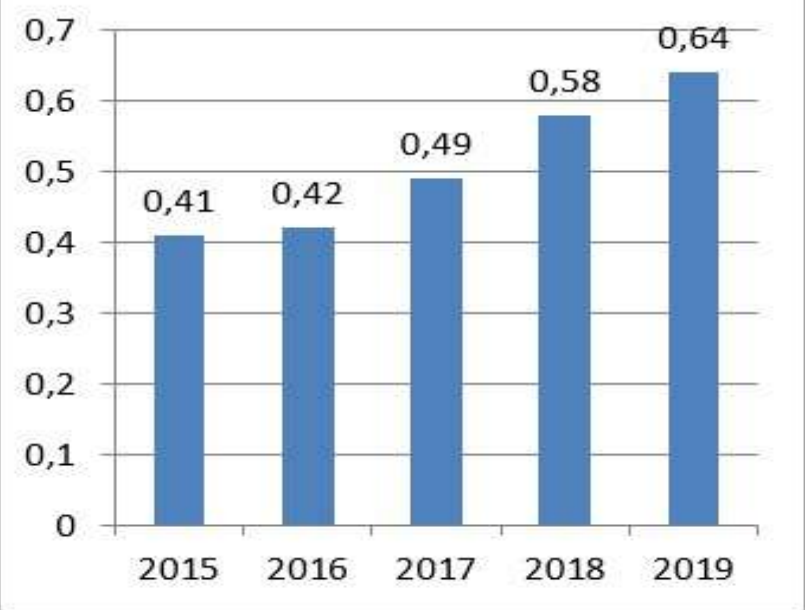


The diagrams show that the share of foreign investment in the GRP of the Surkhandarya region, as well as the region's share of investment development in the Republic, show low indicators. In 2019, the share of foreign investment in GRP amounted to 0.002 units, while the indicator of attracting foreign investment in other regions of our republic in the Surkhandarya region is 6956.5 billion sums. The share of the region in the development of investments in the republic in 2019 amounted to 0.64 units, where the average growth for 2015-2019 is 0.5 units. In the Republic, investment growth remains at the level of 189924.3 billion sums (less than $4 \%$ of GDP). This is lower than the average for countries in transition in the CIS.

In the Surkhandarya region, the indicator of investments in fixed assets per capita is determined by the ratio of the volume of investments for a certain year to the population for the same period.

Based on the data, indicators of the diagram, the population of the Surkhandarya region, we determined the volume of investments per capita in the region, which shows a positive trend. On average, in the region, the per capita investment rate for the period under review amounted to 2150.3 billion sums.
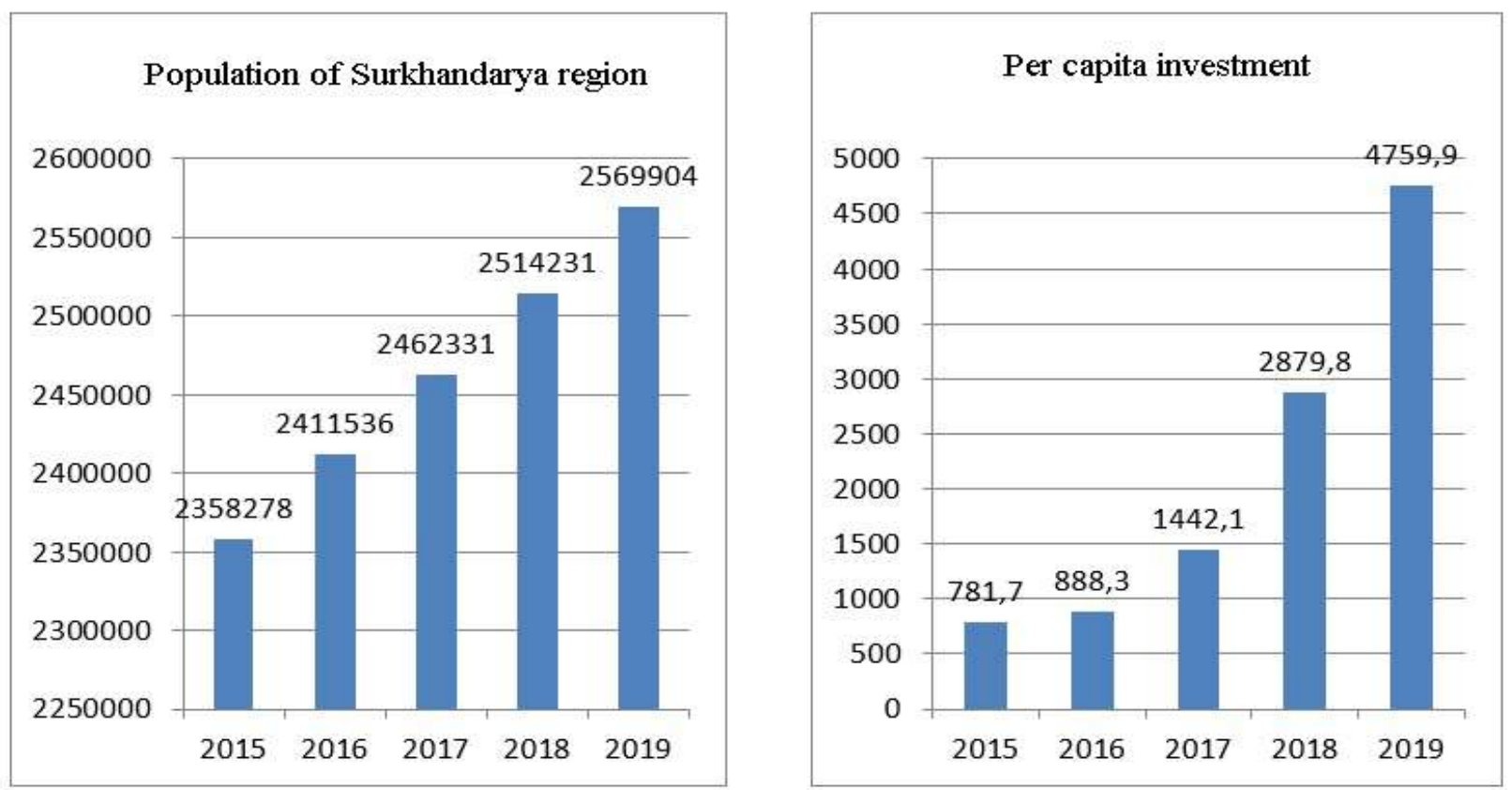

The growth of investments in the Surkhandarya region contributed to the growth of investment activity. The most attractive are the fuel, chemical and petrochemical sectors and energy close to the location rich in water resources. Due to favorable climatic conditions and rich experience in growing raw cotton, processed products are in great demand in the domestic and foreign markets and are attractive for investment in the region.

\begin{tabular}{|l|l|l|l|}
\hline & Total & State & Non-state \\
\hline Total, billion soums & & & \\
\hline Including in relation to everything in\%: & 12232,4 & 1255,8 & 10976,6 \\
\hline Construction and installation work & & & \\
\hline Machines, equipment, inventory & 61,8 & 85,4 & 59,1 \\
\hline Other costs & 28,7 & 11,6 & 30,6 \\
\hline
\end{tabular}

Structure of investment in fixed assets by ownership in the Surkhandarya region (January-December 2019)

In the structure of investments in fixed assets of the Surkhandarya region, the share of construction and installation works is $-61.8 \%$, machinery, equipment and inventory - $28.7 \%$, the share of other costs is $9.5 \%$. 


\begin{tabular}{|l|l|l|l|}
\hline & & $\begin{array}{l}\text { JanuaryDecember } \\
\mathbf{2 0 1 8}\end{array}$ & $\begin{array}{l}\text { JanuaryDecember } \\
\mathbf{2 0 1 9}\end{array}$ \\
\hline Fixed capital investment-total & $\mathbf{1 2 2 3 2 , 4}$ & $\mathbf{1 0 0 , 0}$ & $\mathbf{1 0 0 , 0}$ \\
\hline Including by fields of activity & & & \\
\hline Agriculture, forest and fisheries & 2054,1 & 3,6 & 16,8 \\
\hline Mining industry & 5023,3 & 24,4 & 41,1 \\
\hline Manufacturing industry & 1471,3 & 13,6 & 12,0 \\
\hline Electricity, gas, steam and air conditioning air & 222,8 & 1,5 & 1,8 \\
\hline $\begin{array}{l}\text { water supply; sewage system, waste collection and } \\
\text { disposal }\end{array}$ & 358,9 & 2,9 & 2,9 \\
\hline building & 259,0 & 3,0 & 2,1 \\
\hline $\begin{array}{l}\text { Wholesale and retail trade; repair of motor vehicles and } \\
\text { motorcycles }\end{array}$ & 383,7 & 3,9 & 3,1 \\
\hline Transportation and storage & 396,0 & 16,0 & \\
\hline Accommodation and food services & 60,8 & 0,2 & 3,2 \\
\hline Information and Communication & 42,5 & 0,5 & 0,5 \\
\hline Financial and insurance activities & 29,6 & 0,3 & 0,3 \\
\hline Professional, scientific and technical activities & 10,1 & 0,1 & 0,2 \\
\hline education & 372,3 & 3,2 & 0,1 \\
\hline Health and social services & 228,8 & 3,0 & 3,0 \\
\hline Arts, entertainment and recreation & 45,4 & 0,8 & 1,9 \\
\hline $\begin{array}{l}\text { Other activities: } \\
\text { housing investment }\end{array}$ & 1131,5 & 18,2 & 0,4 \\
\hline Other activities & 142,3 & 4,8 & 9,3 \\
\hline
\end{tabular}

Development of investments in fixed assets in the areas of activity of the Surkhandarya region (2019 year January December)

As you can see from the table, the structure of investments in fixed assets by type of economic activity: in the mining industry, 5023.3 billion soums (41.1\% of the total investment), including 4697.2 billion soums for oil and natural gas. in the manufacturing industry - 1471.3 billion soums (12.0\%), including 396.9 billion soums (3.2\%) of food, beverages and tobacco, 231.2 billion soums of textile products (1.9\%), Production of other non-metallic nominal products amounted to 704.2 billion soums (5.8\%), electricity, gas, steam and air conditioning 222.8 billion soums (1.8\%), water supply; Sewerage, collection and garbage collection 358.9 billion soums (2.9\%), construction work - 259.0 billion soums (2.1\%), wholesale and retail trade, car and motorcycle repair amounted to 383.7 billion. soums (3.1\%), 396.0 billion for transportation and storage (3.2\%), 42.5 billion soums in information and communication activities $(0.3 \%), 10.1$ billion in professional, scientific and technical activities $(0.1 \%)$, in the field of education - 372.3 billion soums (3.0\%), in addition to the total activity of 1131.5 billion soums in housing construction $(9.3 \%)$, investments were disbursed.

\section{Conclusion:-}

Based on the analysis, it can be concluded that in the Surkhandarya region the investment level is relatively low, to a greater extent due to the presence of consumer and labor potential.In the decree of the President of the Republic of Uzbekistan dated April 29, 2019 "On measures to further improve the mechanisms for attracting direct foreign investment in the economy of the Republic", it should be noted that a number of priorities are identified to increase the efficiency of attracting direct foreign investors and opportunities, improving coordination of the activities of local executive authorities, state and economic bodies in the field of attraction and development of foreign investments. In this process, we must understand which sector needs the most foreign investment and which sector plays an important role in the economic growth of the region. It is very important that this sector be supported, because foreign investors, first of all, invest in the sector whose activities bring the greatest profit, and they strive to develop this activity, using all opportunities, to increase the level of profitability and receive greater profit. If the capital in this area does not justify itself, does not find its place in the market, investors take capital from this industry or type of activity and direct it to another more profitable industry.Due to the current distribution situation of COVID-19 around the world, attracting investment is very difficult. Therefore, it is necessary to effectively use the attracted foreign investment, to work intensively and systematically.To actively attract foreign capital to the regions, it is necessary to create an investment image, organize special economic zones, develop the stock market 
and corporate governance, open branches of foreign companies, stimulate the attraction of foreign specialists, and improve the quality of state institutions.

\section{Reference:-}

1. MirziyaevSh.M. Decree of the President of the Republic of Uzbekistan "On measures to further improve the mechanisms for attracting foreign direct investment in the economy of the Republic" on April 29, 2019

2. Trukhin S.A. Assessment of investment attractiveness and innovative potential of the region on the example of the Altai Territory // PolzunovskiyVestnik 2006 №3-1 C200-203

3. Nguyen Thi Thu Thuong Content of the concept of investment attractiveness of Tula, Tula State University №8 (920) S91-96

4. Valiev B. B. Assessment of the investment potential of the regions on the example of the Republic of Uzbekistan. //Moscow. Journal Regional Economics: Theory and Practice No. 4 (2016) 111-130

5. ValiullinH.Kh., Shakirova E.R. Heterogeneity of the investment space of Russia: regional aspect // Problems of forecasting. 2004. No. 1. P. 157-165.

6. Emirullah Ch., Azam M. Examining Public Private Partnerships in ASEAN countries: the role of investment climate // Theoretical and Applied Economics. 2014. Vol. XXI. No. 2. P. 6776.

7. www.stat.uz. 